\title{
Effect of Dietary Growth Promoters on Some Physiological Responses of Growing Rabbits
}

\section{SA Abd EL-Latif*, MA Toson, HA M Elwan and Esraa S Helpawy}

Department of Animal Production, Faculty of Agriculture, Minia University, Minia, Egypt

*Corresponding Author: SA Abd EL-Latif, Department of Animal Production, Faculty of Agriculture, Minia University, Minia, Egypt.

Received: September 19, 2019; Published: October 21, 2019

DOI: 10.31080/ASMS.2019.03.0442

\begin{abstract}
This study was conducted to investigate the effects of phytogenic additives i.e. turmeric powder, ginger powder, fenugreek seeds powder, dried lemon powder on some physiological responses of growing rabbits. A total of 30, New Zealand White rabbits (NZW) at 5 weeks of age were randomly assigned to five treatments with three replicates. The dietary treatments consisted of 5 groups as follows; the basal diet as control, phytogenic additives groups were supplemented with $0.5 \%$ turmeric powder, $0.5 \%$ ginger, $1.0 \%$ fenugreek seeds and $1.0 \%$ dried lemon added to the basal diet. The data revealed that, there were no significant $(\mathrm{P}>0.05)$ differences in total erythrocyte count (RBC's), Packed Cell Volume (PCV\%), Hemoglobin percentage (Hb\%), total protein, albumin, globulin, total cholesterol, glucose among dietary treatments and control. Rabbits fed diets incorporated with $0.5 \%$ ginger, $1.0 \%$ fenugreek, or $0.5 \%$ curcuma showed significant decreased $(\mathrm{p} \leq 0.05)$ in triglycerides.
\end{abstract}

Keywords: Rabbits; Physiological Responses; RBC'S

\section{Introduction}

Rabbits are hoped to play an important role in solving meat production deficiency particularly in developing countries, because they have several advantages (small body size, high growth rate, high efficiency in converting feed into meat, short gestation period, high prolificacy, relatively low cost of production and high nutritional quality of its meat which includes low fat, sodium and cholesterol levels, [1] that support the increase of its use for human consumption [2]. This requires the increase of the production of livestock to meet the protein demand from the population.

Feed additives represent various classes of molecules, compounds, or organisms that promote ingestion, absorption, assimilation of nutrients, growth, and health. They affect physiological processes, such as immune function, stress resistance, and reproduction. Feed additives include feeding attractants, immunostimulants, prebiotics, probiotics, acidifiers, essential oils, or other inclusions [3].
The aim of this study was to evaluate the consequence of adding some natural feed additives i.e. turmeric, ginger, fenugreek and dried lemon to rabbit diets at the levels of $0.5,0.5,1.0$, and $1.0 \%$ respectively, on some physiological responses.

\section{Materials and Methods}

Experimental animals

A total number of 30 males, 5 weeks old growing New Zealand white rabbits were used to study the effect of some natural feed additives on growth performance, some carcass traits and digestibility of nutrients. Rabbits distributed into ( 5 treatments $x 3$ replicates $x 2$ rabbit $=30$ rabbits). All rabbits were housed in open house. The rabbits were allocated in a cage with slatted floor of iron. The dimensions of the cage were $(45 \times 45 \times 38 \mathrm{~cm})$ for length, width and high, respectively. Feed and water given to the rabbits ad-libitum during the experimental periods. 


\section{Experimental Diets}

Growing rabbits were distributed to same five dietary treatment groups as their mothers. The first group fed control diet formulated to contain adequate levels of nutrients for growing New Zealand White rabbits as recommended by the National Research Council, [4]. The formulation and chemical composition of control diet is shown in (Table 1). Chemical analysis of ingredients and diets was determined according to [5]. Four additional dietary treatment groups were formulated to contain control diet incorporated with feed supplementation according to the source of addition such as $0.5 \%$ curcuma, $0.5 \%$ ginger, $1.0 \%$ fenugreek and $1.0 \%$ dried lemon respectively.

\begin{tabular}{|l|c|}
\hline Ingredients & \% \\
\hline Ground yellow corn & 54.0 \\
\hline Soya bean meal & 20.3 \\
\hline Wheat bran & 5.0 \\
\hline Lime stone & 0.3 \\
\hline Berseem hay & 18.8 \\
\hline Dicalcium phosphate & 1.0 \\
\hline Salt & 0.3 \\
\hline Premix & 0.3 \\
\hline Total & 100 \\
\hline \multicolumn{1}{|c|}{ Calculated analyses\% $\%$} \\
\hline Crude protein, & 17.4 \\
\hline ME (Kcal/ kg) & 2561.7 \\
\hline Crude fiber, & 7.8 \\
\hline Calcium, & 0.68 \\
\hline Available phosphorus, & 0.33 \\
\hline Methionine+ cysteine, & 0.57 \\
\hline Lysine, & 0.85 \\
\hline
\end{tabular}

Table 1: The composition and chemical analysis of control diet of growing New Zealand White rabbits.

*Each $2.5 \mathrm{~kg}$ of vitamins and minerals mixture contains: 12000.000 IU vitamin A acetate; 2000.000 IU vitamin D3; 10.000 mg vitamin E acetate; $2000 \mathrm{mg}$ vitamin K3; $100 \mathrm{mg}$ vitamin B1; 4000 mg vitamin B2; $1500 \mathrm{mg}$ vitamin B6; $10 \mathrm{mg}$ vitamin B12; $10.000 \mathrm{mg}$ pantothenic acid; $20.000 \mathrm{mg}$ Nicotinic acid ; $1000 \mathrm{mg}$ Folic acid; $50 \mathrm{mg}$ Biotin; 500.000 mg chorine; 10.000 mg Copper; 1000 mg Iodine; 300.000 mg Iron; 55.000 mg Manganese; 55.000 mg Zinc, and 100 gm Selenium.
Heamatological blood parameters

Total erythrocyte count

Total erythrocyte count (RBC's), were performed using a veterinary hematology analyzer (Vet Scan HM5 Haematology System Abaxis Europe, UK).

\section{Hemoglobin percentage ( $\mathrm{Hb} \%)$}

Whole blood hemoglobin concentration ( $\mathrm{Hb}$ ) was performed using a veterinary hematology analyzer (Vet Scan HM5 Hematology System Abaxis Europe, UK).

Packed Cell Volume (PCV\%)

Packed Cell Volume was performed using a veterinary hematology analyzer (Vet Scan HM5 Hematology System Abaxis Europe, UK).

Serum biochemical parameters

Total protein concentration $(\mathrm{g} / \mathrm{dl})$

Serum total protein content was determined according to the method of [6] using reagent kits purchased from Biodiagnostic chemical company (Egypt).

Albumin concentration (g/dl)

Serum albumin concentration was determined according to the method of [7] using reagent kits purchased from Biodiagnostic chemical company (Egypt).

Globulin concentration (g/dl)

Serum globulin concentration was calculated using the following equations:

Globulin $(\mathrm{g} / \mathrm{dl})=$ Total proteins $(\mathrm{g} / \mathrm{dl})-\operatorname{Albumin}(\mathrm{g} / \mathrm{dl})$

Serum triglycerides (mg/dl)

Serum triglycerides were determined according to [8] using reagent kits purchased from Biodiagnostic chemical company (Egypt).

Total cholesterol (mg/dl)

Serum cholesterol was determined according to [9] using reagent kits purchased from Biodiagnostic chemical company (Egypt).

\section{Glucose concentration (mg/dl)}

Serum glucose concentration was determined according to the method of [10] using reagent kits purchased from Biodiagnostic chemical company (Egypt). 


\section{Statistical analysis}

Data were summarized using Microsoft $^{\circledR}$ Excel 2010 (10.2614.2625) Microsoft Egypt. The general liner model (GLM) was applied to test the differences among the five experimental groups. P-values less than 0.05 were considered to be statistically significant [11]. The statistical analysis was calculated using the following equation:

\section{$\mathbf{Y i j}=\boldsymbol{\mu}+\mathbf{T i}+\mathbf{E} \mathbf{i j}$}

Where:

Yij = Experiment observations.

$\mu=$ The overall mean.

$\mathrm{Ti}=$ The effect of dietary treatment.

$\mathrm{i}=\mathrm{T} 1,----\mathrm{T} 5$.

Eij $=$ The experimental error.

Duncan's test was used to examine the significance degrees among means [12].

\section{Results and Discussion}

Hematological parameters

Averages of RBC's count, Hb.\% and PCV\% of New Zealand White rabbits fed different diet supplemented with $0.5 \%$ curcuma, $0.5 \%$ ginger, $1.0 \%$ fenugreek and 1.0 dried lemon are presented in (Table 2). No significant $(\mathrm{P}>0.05)$ difference was detected among all dietary treatments on RBC's count, $\mathrm{Hb} \%$ and PCV\%. Whereas, rabbits fed dietary ginger recorded slightly higher values $(\mathrm{P}>0.05)$ in the previous items compared with other dietary treatments.

\begin{tabular}{|l|c|c|c|}
\hline \multirow{2}{*}{ Treatment } & \multicolumn{3}{|c|}{ Hematological responses } \\
\cline { 2 - 4 } & RBC's 10 $\boldsymbol{~}^{\text {l }}$ & Hb. \% & PCV\% \\
\hline Control & 6.19 & 12.90 & 41.92 \\
\hline Curcuma, 0.5\% & 5.82 & 12.63 & 38.38 \\
\hline Ginger, 0.5\% & 7.16 & 13.33 & 44.54 \\
\hline Fenugreek, 1.0\% & 6.37 & 11.87 & 38.82 \\
\hline Lemon, 1.0\% & 6.64 & 12.40 & 43.69 \\
\hline \pm SE & 0.30 & 0.56 & 2.46 \\
\hline Sig. & NS & NS & NS \\
\hline
\end{tabular}

Table 2: Effect of natural feed additives on hematological parameters.

SE: - standard error $( \pm)$. NS: - Not significant $(P>0.05)$.
Spice as an additive in the diet of chickens is very common. Active principles of the plant or plant chemicals present in certain parts of the plant or the effect of the rape tic activity that accompanies them [13]. In this study, the apparent improvement of dietary ginger powder could be due to their antioxidant and antimicrobial properties $[14,15]$. Hence, ginger could play an important role in rabbit feeding strategy. Moreover, important compound in ginger, gingerol, ginger diol and ginerdione had the ability to stimulate the digestive enzymes, the impact on microbial activity [16] in broiler. Reported that various medical properties of ginger (such as showing pain) analgesic, antiemetic, antiulcer (febrifuge) antipyretic and Cardiac relaxing. [17-19] and reduced anti oxidation free harm, increased reuse and improve the health and production of animals.

The previous results are in line of the finding of [20] and [21] who observed the infusion of ginger root powder in broiler chick was not significantly affecting the blood parameters with respect to hemoglobin concentration, RBC and Packed cell volume percentage. However. [22] found an increasing in packed cell volume and hemoglobin concentration in broiler chickens provided with ginger root powder.

\section{Biochemical blood parameters}

Data of blood biochemical studied such as total protein, albumin, globulin, glucose, triglycerides and cholesterol for dietary treatments are presented in (Table 3). The results revealed that there was a significant difference in triglycerides among all dietary treatments. Rabbits fed diets incorporated with 0.5\% ginger, 1.0\% fenugreek, or $0.5 \%$ curcuma showed significant decreased $(\mathrm{p} \leq$ $0.05)$ in triglycerides. However, no significant difference $(P>0.05)$ was detected in total protein, albumin, globulin, glucose and cholesterol among all dietary treatments.

The reduction of lipids profile triglycerides (TG) may be due to that curcumin enhances bile production and hence lipid digestion [23].

The previous results are parallel with the finding of [24] found that male rabbits fed $2 \%$ ginger powder showed significant decreased in triglycerides. Moreover, [25] showed significant $(\mathrm{P} \leq$ 0.05 ) decrease in serum triglycerides level when rabbits fed on diet contain 0.0, 0.5 and 1 gram of fenugreek compared to the control group. Also, [26] demonstrated that, triglycerides were statistically decreased with increasing turmeric levels to $7 \mathrm{~g} / \mathrm{kg}$ diet in broilers. 


\begin{tabular}{|l|c|c|c|c|c|c|}
\hline Treatment & $\begin{array}{c}\text { Total protein } \\
\text { (g/dl) }\end{array}$ & $\begin{array}{c}\text { Albumin } \\
\text { (g/dl) }\end{array}$ & $\begin{array}{c}\text { Globulin } \\
\text { (g/dl) }\end{array}$ & $\begin{array}{c}\text { Glucose } \\
\text { (mg/dl) }\end{array}$ & $\begin{array}{c}\text { Triglycerides } \\
\text { (mg/dl) }\end{array}$ & $\begin{array}{c}\text { Total cholesterol } \\
\text { (mg/dl) }\end{array}$ \\
\hline Control & 5.51 & 2.76 & 2.75 & 103.75 & $168.58^{\mathrm{a}}$ & 190.17 \\
\hline Curcuma, 0.5\% & 5.46 & 2.88 & 2.58 & 104.85 & $156.89^{\mathrm{abc}}$ & 210.88 \\
\hline Ginger, 0.5\% & 5.60 & 2.96 & 2.64 & 101.09 & $146.41^{\mathrm{c}}$ & 212.57 \\
\hline Fenugreek,1.0\% & 5.68 & 2.75 & 2.93 & 99.54 & $150.52^{\mathrm{c}}$ & 206.50 \\
\hline Lemon, 1.0\% & 5.78 & 2.92 & 2.68 & 103.68 & $163.92^{\mathrm{ab}}$ & 210.93 \\
\hline \pm SE & 0.11 & 0.10 & 0.16 & 2.38 & 5.00 & 7.71 \\
\hline Sig. & NS & NS & NS & NS & $*$ & NS \\
\hline
\end{tabular}

Table 3: Effect of natural feed additives on some biochemical parameters.

[27] Established that cholesterol due to the dietary of broilers rabbits inclusion of turmeric powder rhizome supplementation at $0,0.15$ and 0.30 percent did not show significant difference among the treatment groups.

Also, [28] reported that, supplementation of ginger at the rate of $2 \mathrm{~g}, 4 \mathrm{~g}$ and $6 \mathrm{~g} / \mathrm{kg}$ did not affect total cholesterol in the serum of broiler chickens. In addition, [29] found that, serum cholesterol level were not significantly ( $p>0.05$ ) altered by dietary fenugreek. Likewise, [30] revealed that there were no statistically significant differences in terms of total cholesterol, after feeding growing rabbits dried citrus pulp. Likewise, [31] revealed that, there were no statistically significant differences in terms of blood serum cholesterol, after the groups were fed according to the diets as $0.5 \%$ sumac, $0.5 \%$ turmeric, and $0.25 \%$ sumac $+0.25 \%$ turmeric in the diet of laying hens.

Ethics statement

In this study, the animal care and use procedures were approved by the Department of Animal and Poultry Production, Faculty of Agriculture, Minia University, Egypt. Animal care and maintenance were following the guidelines of the Egyptian Research Ethics Committee and the instructions contained in the Guide for the Care and Use of Laboratory Animals (2011).

\section{Bibliography}

1. Marai IFM., et al. "Criteria of response and adaptation to high temperature for reproductive and growth traits in rabbits". Options Mediterraneans Seree A 17 (1991):127-134.

2. Dacinia-Crina P., et al. "Rabbit statistics overview: production, trade, market evolution”. Rabbit Genetics 3 (2013): 15-22.
3. Stephen A Watts and John M Lawrence. "Developments in Aquaculture and Fisheries Science”. Science Direct (2013).

4. National Research Council (NRC). "Nutrient Requirements of Poultry". 9th rev. ed. Natl. Res. Counc, Natl. Acad. Press, Washington, DC (2004).

5. AOAC. "Official Methods of Analysis, 17th ed". Association of Official Analytical Chemists, Arlington VA (2000).

6. Gornall AG., et al. "Determination of serum proteins by means of the biuret reaction". Journal of Biological Chemistry 177.2 (1949): 751-766.

7. Doumas BT and Peters Jr T. "Serum and urine albumin: a progress report on their measurement and clinical significance". Clinica Chimica Acta 258.1 (1997): 3-20,

8. Fossati P and Prencipe L. "Serum triglycerides determined colorimetrically with an enzyme that produces hydrogen peroxide". Clinical Chemistry 28.10 (1982): 2077-2080.)

9. Richmond W. "Preparation and properties of a cholesterol oxidase from Nocardia sp. and its application to the enzymatic assay of total cholesterol in serum". Clinical Chemistry 19.12 (1973): 1350-1356.

10. Trinder P. "Determination of glucose in blood using glucose oxidase with an alternative oxygen acceptor". Annals of Clinical Biochemistry 6.1 (1969): 24-27.

11. SAS Institute. "SAS User"s Guide: Statistics". SAS Institute, Cary NC (2003).

12. Duncan DB. "Multiple ranges and multiple F-tests". Biometric 11 (1955): 1042. 
13. Zhang GF., et al. "Effects of ginger root (Zingiber officinale) processed to different particle sizes on growth performance, antioxidant status, and serum metabolites of broiler chickens". Poultry Science 88.10 (2009): 2159-2166.

14. Zomrawi WB., et al. "The effect of ginger root powder (Zingiber officinale) supplementation on broiler chick's performance, blood and serum constituents". Online Journal of Animal and Feed Research 2 (2012): 457-460.

15. Mancini S., et al. "Modifications of fatty acids profile, lipid peroxida- tion and antioxidant capacity in raw and cooked rabbit burgers added with ginger". Meat Science 133 (2017): 151158.

16. Dieumou FE., et al. "Effects of ginger (Zingiber officinale) and garlic (Allium sativum) essential oils on growth performance and gut microbial population of broiler chickens". Livestock Research for Rural Development 21.8 (2009): 23-32.]

17. Mascolo N., et al. "Ethnopharmacologic investigation of ginger (Zingiber officinale)". Journal of Ethnopharmacology 27.1-2 (1989): 129-140.,

18. Philips S., et al. "Zingiber officinale (ginger) an Phosphorus". D. Hamlyn. London, New York. SYndeny, Toronto (1993).

19. Utpalendu J., et al. "Preliminary studies on anti-inflammatory activity of Zingiber officinale Rosc., Vitex negundo Linn and Tinospora cordifolia (willid) Miers in albino rats". Indian Journal of Pharmacology 31.3 (1999): 232.

20. Zomrawi WB., et al. "The effect of ginger root powder (Zingiber officinale) supplementation on broiler chick's performance, blood and serum constituents". Online Journal of Animal and Feed Research 2 (2012): 457-460.

21. Zomrawi WB., et al. "The effect of dietary ginger root powder (zingiber officinale) on broiler chick's performance, carcass characteristic and serum constituents". Journal of Animal Science Advances 3 (2013): 42-47.

22. Al-Moramadhi SAH. "The effect of Zingiber officinali roots infusion on some physiological parameters in broiler chickens". Kufa Journal for Veterinary Medical Sciences 1.2 (2010): 67-76.

23. Al-Sultan SI and Gameel AA. "Histopathological changes in the livers of broiler chicken supplemented with turmeric (Curcuma longa)". International Journal of Poultry Science 3.5 (2004): 333-336.
24. Lebda M., et al. "Biochemical effect of ginger on some blood and liver parameters in male New Zealand rabbits". Online Journal of Animal and Feed Research 2.2 (2012): 197-202.

25. Elseed AMAF., et al. "Effects of Fenugreek (Trigonella foenumgraecum) Seeds Saponin on Digestibility, N-Retention, Hematological Parameters and Blood Metabolites in Rabbits". World's Veterinary Journal 3 (2013): 65-73.

26. Hussein SN. "Effect of turmeric (Curcuma longa) powder on growth performance, carcass traits, meat quality, and serum biochemical parameters in broilers". Journal of Advanced Biomedical and Pathobiology Research 3 (2013): 25-32.

27. Basavaraj M., et al. "Effect of dietary supplementation of Curcuma Longa on the biochemical profile and meat characteristics of broiler rabbits under summer stress". Veterinary World 4.1 (2011): 15.

28. George OS., et al. "Effects of graded levels of ginger (Zingiber officinale) meal as feed additive on growth performance characteristics of broiler chicks". International Journal of Science and Research 3 (2013): 805-808.

29. Weerasingha AS and Atapattu NSBM. "Effects of Fenugreek (Trigonella foenum-graecum L.) seed powder on growth performance, visceral organ weight, serum cholesterol levels and the nitrogen retention of broiler chicken".| Tropical Agricultural Research 24.3 (2013): 289-295.

30. Lu J., et al. "Effect of dietary inclusion of dried citrus pulp on growth performance, carcass characteristics, blood metabolites and hepatic antioxidant status of rabbits". Journal of Applied Animal Research 46.1 (2018): 529-533.

31. Gumus H., et al. "Effects of sumac and turmeric as feed additives on performance, egg quality traits, and blood parameters of laying hens". Revista Brasileira de Zootecnia (2018): 47.

\section{Volume 3 Issue 11 November 2019 (C) All rights are reserved by SA Abd EL-Latif., et al.}

